\title{
Analisis Dampak Digital Banking Dan Kualitas Pelayanan Terhadap Kepuasan Nasabah Pada Sebuah Bank Swasta
}

\author{
Mita Sicillia'. Abu Yazid ${ }^{2}$ \\ Universitas Pamulang \\ Email : dosen02191@gmail.com; dosen01470@unpam.ac.id
}

\begin{abstract}
Abstrak. Penelitian ini memiliki tujuan untuk menganalisa dampak dari Digital Banking dan Kualitas Pelayanan terhadap Kepuasan Nasabah pada PT. Bank OCBC NISP, Tbk. Jenis penelitian kuantitatif dengan jumlah sampel 100 orang responden yang merupakan nasabah PT. Bank OCBC NISP, Tbk. Data diumpulkan melalui wawancara kuisioner. Data dianalisa menggunakan uji hipotesis. Pengujian yang telah dilakukan menghasilkan adanya pengaruh digital banking dan kualitas pelayanan secara bersama-sama terhadap kepuasan nasabah secara statistik menghasilkan nilai positif dan juga signifikan diperoleh nilai $F$ hitung 39,917 dan $F$ tabel 2,70. Nilai $F$ hitung tersebut > F tabel, hal tersebut membuktikan bahwa pengaruh tersebut berdampak positif dan signifikan. Oleh karena itu dapat disimpulkan variabel digital banking dan kualitas pelayanan secara bersama-sama berpengaruh positif dan signifikan terhadap kepuasan nasabah pada PT. Bank OCBC NISP, Tbk.
\end{abstract}

Kata Kunci : Digital Banking; Kualitas Pelayanan; Kepuasan Nasabah

Abstract. This research has the aim to analyze the effect of Digital Banking and Services Quality on Customer Satisfaction of PT. Bank OCBC NISP, Tbk. The research method used in this research is quantitative with a sample size of 100 respondents, data collection by interview and questionnaire. Data analysis using hypothesis test. From the tests result shows that there are the simultaneous effect of digital banking and services quality on customer satisfaction, statistically showing positive and significant results. This is indicated by the calculated $F$ value of 39,917 with the F table is 2,70. The value of $F$ count $>F$ table indicates that the effect is positive and significant.

Keywords: Digital Banking; Service Quality; Customer Satisfaction

\section{A. PENDAHULUAN}

Digital banking merupakan teknologi aplikasi didalam dunia bisnis perbankan hal ini adalah layanan yang diberikan perbankan dengan memanfaatkan teknologi digital bagi kebutuhan nasabah untuk menghadapi perkekonomian digital yang sangat berkembang dengan pesat. Beberapa jenis digital banking yang telah diterapkan selama ini adalah ATM, mobile banking, internet banking, SMS banking dll. Selain itu terdapat bank lainnya yang juga telah melakukan pengurangan cabang guna meminimalisir biaya operasional perusahaan tersebut. Masyarakat semakin banyak yang beralih melakukan transaksi perbankan dari konvesional menjadi melalui e-banking, hal ini ditunjukkan dimana kantor-kantor cabang bank sudah mulai sepi dikarenakan mayoritas nasabah menggunakan fasilitas digital 
banking tanpa harus datang ke bank. Pertumbuhan transaksi non tunai akan terus meningkat sejalan dengan kemajuan teknologi dan perubahan perilaku masyarakat. Daya tarik digital banking adalah fitur yang dimilikinya dimana nasabah mendapatkan kemudahan dan kenyamanan didalam bertransaksi baik dalam melakukan pengiriman uang antar bank, pemindah bukuan sesama bank maupun bertransaksi pembayaran tagihan.

Awal berdiri Bank OCBC NISP pada tahun 1941 yang bertempat di Bandung, Bank NISP adalah nama perusahaan sebelum menjadi PT.Bank OCBC. Bank OCBC NISP terus melakukan perubahan hingga akhirnya menjadi perusahaan go publik.

Rumusan masalah penelitian ini adalah untuk menganalisa apakah digital banking berpengaruh positif dan signifikan terhadap kepuasan nasabah, apakah kualitas pelayanan berpengaruh positif dan signifikan terhadap kepuasan nasbah dan apakah digital banking dan kualitas pelayanan secara bersama-sama berpengaruh terhadap kepusan nasabah.

Tujuan penelitian ini adalah untuk mengetahui pengaruh digital banking terhadap kepuasan nasabah, untuk mengetahui pengaruh kualitas pelayanan terhadap kepuasan nasabah dan untuk mengetahui digital banking dan kualitas pelayanan secara simultan berpengaruh terhadap kepuasan nasabah.

\section{B. KAJIAN LITERATUR}

Digital banking adalah alat penting bagi kelangsungan hidup dan menyebabkan perubahan mendasar dalam industri perbankan diseluruh dunia. Saat ini, layanan perbankan yang ditawarkan kepada pelanggan tanpa memerlukan kehadiran fisik mereka di bank dalam waktu singkat dan dengan biaya minimal (Susanto, Aries, 2013)

Kualitas pelayanan yaitu suatu cara untuk memenuhi kemauan dan kebutuhan konsuman dan juga pemberian penyampaian yang tepat untuk memenuhi harapan konsumen (tjiptono, 2007).

Philip Kotler (2002 : 42) "Kepuasan konsumen adalah perasaan senang atau kecewa seseorang yang berasal dari perbandingan antara kesannya terhadap kinerja (atau hasil) suatu produk dan harapan-harapannya".

\section{METODOLOGI PENELITIAN}

Terdapat metode dan teknik yang diterapkan dalam penelitian ini, yang pertama yairu metode kuantitatif adapun tekniknya yaitu dengan mengumpulkan data melalui kuisioner diberikan kepada nasabah Bank OCBC NISP sejumlah 100 responden, penelitian dibuat dalam bentuk paragraf mengalir data dianalisa dengan uji hipotesis. 
ISSN NO. (PRINT) 2598-0823, (ONLINE) 2598-2893

\section{HASIL DAN PEMBAHASAN}

\section{Tabel 1: Hasil uji t Digital Banking Terhadap Kepuasan Nasabah}

\begin{tabular}{|c|c|c|c|c|c|c|}
\hline \multirow[b]{3}{*}{ Model } & & \multicolumn{2}{|c|}{ Coefficients $^{a}$} & \multirow[b]{2}{*}{ Standardized Coefficients } & \multirow[b]{3}{*}{$\mathrm{t}$} & \multirow[b]{3}{*}{ Sig. } \\
\hline & & \multicolumn{2}{|c|}{$\begin{array}{l}\text { Unstandardized } \\
\text { Coefficients }\end{array}$} & & & \\
\hline & & $\mathrm{B}$ & Std. Error & Beta & & \\
\hline 1 & (Constant) & 15,507 & 3,244 & & 4,780 &, 000 \\
\hline & Digital_Banking &, 628 &, 078 &, 629 & 8,006 &, 000 \\
\hline
\end{tabular}

a. DependentVariable:Kepuasan_Nasabah

\section{Sumber: Hasil Pengolahan Data}

Tabel 1 tersebut menginformasikan bahwa untuk variabel digital banking memiliki nilai $\mathrm{t}$ hitung 8,006 dimana nilai tersebut melebihi nilai t tabel $1,98(8,006>1,98)$ dan memiliki nilai signifikan 0,000 dimana nilai tersebut kurang dari dari nilai $0,05(0,000<0,05)$.

Berdasarkan data yang telah diolah diatas maka keputusan yang bisa diambil adalah Ho ditolak dan Ha diterima, berdasarkan uji t tersebut bisa diambil kesimpulan yaitu Digital Banking(X1) mempunyai pengaruh signifikan terhadap Kepuasan Nasabah (Y) .

Tabel 2: Hasil Uji t Kualitas Pelayanan terhadap Kepuasan Nasabah

\begin{tabular}{|c|c|c|c|c|c|c|}
\hline \multicolumn{7}{|c|}{ Coefficients $^{a}$} \\
\hline \multirow[b]{2}{*}{ Model } & & \multicolumn{2}{|c|}{$\begin{array}{l}\text { Unstandardized } \\
\text { Coefficients }\end{array}$} & \multirow{2}{*}{$\begin{array}{c}\text { Standardized } \\
\text { Coefficients } \\
\text { Beta }\end{array}$} & \multirow[b]{2}{*}{$\mathrm{T}$} & \multirow[b]{2}{*}{ Sig. } \\
\hline & & $\mathrm{B}$ & Std. Error & & & \\
\hline \multirow[t]{2}{*}{1} & (Constant) & 23,387 & 2,432 & & 9,615 &, 000 \\
\hline & Kualitas_Pelayanan & 442 & 059 & 601 & 7,449 &, 000 \\
\hline
\end{tabular}

a. DependentVariable:Kepuasan_Nasabah

Sumber: Hasil Pengolahan Data

Tabel 2 tersebut menginformasikann bahwa untuk variabel kualitas pelayanan memiliki nilai $t$ hitung 7,449 dimana nilai tersebut melebihi nilai t tabel $1,98 \quad(7,449>1,98)$ dan memiliki nilai signifikan 0,000 dimana nilai tersebut kurang dari dari nilai $0,05(0,000<0,05)$. 
Berdasarkan data yang telah diolah diatas maka keputusan yang bisa diambil adalah Ho ditolak dan Ha diterima, berdasarkan uji t tersebut bisa diambil kesimpulan bahwa Kualitas Pelayanan (X2) berpengaruh signifikan terhadap Kepuasan Nasabah (Y) .

Untuk megetahu apakah terdapat hubungan antara variabel independen $(X 1, X 2)$ terhadap variabel dependen $(\mathrm{Y})$ secara simultan dan apakah hubungan dan pengaruhnya signifikan atau tidak maka dilakukan uji $F$.

Tabel 3 : Hasil Uji Hipotesis F Digital Banking dan Kualitas Pelayaan berpengaruh terhadap Kepuasan Nasabah

\begin{tabular}{|c|c|c|c|c|c|c|}
\hline \multicolumn{7}{|c|}{ ANOVA $^{a}$} \\
\hline Model & & $\begin{array}{l}\text { Sum of } \\
\text { Squares }\end{array}$ & df & $\begin{array}{c}\text { Mean } \\
\text { Square }\end{array}$ & $\mathrm{F}$ & Sig. \\
\hline \multirow[t]{3}{*}{1} & Regression & 521,797 & 2 & 260,899 & 39,917 &, $000^{\circ}$ \\
\hline & Residual & 633,993 & 97 & 6,536 & & \\
\hline & Total & 1155,790 & 99 & & & \\
\hline
\end{tabular}

Sumber: Hasil Pengolahan Data

Tabel 3 tersebut menunjukkan bahwa nilai $F$ hitung adalah 39,917 sedangkan nilai $F$ tabel adalah 2,70 (taraf signifikan 5\%) sehingga $F$ nilai hitung melebihi nilai $F$ tabel $(39,917>2,70)$.

Dari data tersebut maka keputusan yang bisa diambil adalah Ho ditolak dan Ha diterima , berdasarkan uji $F$ tersebut bisa diambil kesimpulan yaitu Digital Banking (X1) dan Kualitas Pelayanan (X2) berpengaruh signifikan terhadap Kepuasan Nasabah (Y) secara simultan .

\section{E. KESIMPULAN}

1. Secara statistik didapatkan dampak Digital Banking terhadap Kepuasan Nasabah adalah positif dan sigifikan. Terbukti dengan adanya t hitung 8,006 melebihi t tabel 1,98 .

2. Secara statistik didapatkan hasil pengujian dampak Kualitas Pelayanan terhadap Kepuasan Nasabah adalah positif dan signifikan. Terbukti dengan adanya $t$ hitung 7,449 melebihi t tabel 1,98.

3. Secara statistik hasil pengujian yg dilakukan yaitu adanya pengaruh Digital Banking dan Kualitas Pelayanan terhadap Kepuasan Nasabah positif dan signifikan secara simultan. Terbukti adanya F hitung 39,917 melebihi F tabel 2,70. 
ISSN NO. (PRINT) 2598-0823, (ONLINE) 2598-2893

\section{DAFTAR PUSTAKA}

Casalo, L.V., Flavian, C.,\&Guinaliu, M.(2008). The Role of satisfaction and website Usability in Developing Customer Loyalty and Positive Word-of-Mouth in the EBanking Services. The International Journal of Bank Marketing, 26(6):399-417

Chen and Chen. (2009). Determinants of satisfactiion and continuance intenion towards self service technoloies.Industrial Management \& Data Sysems. Vol.109 No 9, 2009 pp 1248-263

Duwi Priyatno.(2014). SPSS 22 Pengolah Data Terpraktis, Andi Offset, Yogyakarta.

Etta Mamang Sangadji dan Sopiah.(2013). Perilaku Konsumen Disertai Himpunan Jurnal Penelitian, Andi Offset, Yogyakarta.

Freddy Rangkuti. (2015). Riset Pemasaran, Gramedia, Jakarta.

Juli Irmayanto dkk.(2004).Bank dan Lembaga Keuangan, Universitas Trisakti, Jakarta Kadir.(2016). Statistika Terapan, RajaGrafindo Persada, Jakarta

Kasmir.(2014). Bankdan Lembaga Keuangan Lainnya, Raja Grafindo Persada, Jakarta

M. Manullang.(2012). Dasar-Dasar Manajemen, Gadjah Mada University Press, Yogyakarta

Philip Kotler and Kevin Lane Keller,(2009). Manajemen Pemasaran, PT Macanan Jaya Cemerlang, Klaten.

V. Wiratna Sujarweni.(2014). Metodologi Penelitian, Pustakabarupress, Yogyakarta.

Https://www.ocbcnisp.com/Groups/Tentang-OCBC-NISP/Brief-Hostory. 